\title{
INNOVATION MANAGEMENT IN THE AREA OF FINANCES AND ACCOUNTING IN THE SME SECTOR
}

doi:10.2478/czoto-2021-0029

Date of submission of the article to the Editor: 01/12/2020

Date of acceptance of the article by the Editor: $24 / 03 / 2021$

\author{
Monika Kapler ${ }^{1}$-orcid id: 0000-0003-0235-7727 \\ ${ }^{1}$ Częstochowa University of Technology, Poland
}

\begin{abstract}
In the era of strong economic development, one of the elements of a company's competitiveness is innovation. It determines the company's development and its success. Appropriate management of innovations in a company determines specific activities in the areas - search, planning, implementation, diffusion and control. Innovations can be about products, processes, organization and marketing. There are many innovations in the financial sector that increase the quality and efficiency of work. This article presents the results of a study conducted using a survey among financial services companies and companies that use a number of financial and accounting innovations in their activities to improve their activities in this area. The research was carried out at the end of 2019 in 40 enterprises of the SME sector in the Śląskie Voivodeship. The results of the research were compared with the prevailing trends both in Poland and in the world, based on publicly available reports and messages. Thegoalof this article is to draw attention to the level of innovative activity in the financial and accounting area of enterprises from the SME sector, and to identify and analyze the elements of managing these innovations in the explored enterprises.
\end{abstract}

Keywords: innovations, enterprises from the SME sector, innovations in the area of finance and accounting, competitiveness.

\section{INNOVATIVE ACTIVITY IN POLAND AND IN THE WORLD - INTRODUCTION}

Innovation has a special role among the factors that influence the company's competitiveness. Regardless of the scale of the business, innovations affect the broadly understood development of the company. The origin of the word "innovation" comes from the Latin word "innowavio", which means renewal (PWN Encyclopedia, 1980). It was first used by J. Schumpeter in economic sciences. He understood them as the introduction of a new product or method (Schumpeter, 1960). The concept of innovation has evolved over time. For example, Philip Kotler applied the concept of innovation to any good, service or idea that someone perceives as new. An idea may have existed for a long time, but it is an innovation for a person who perceives it as innovative (Kotler, 1994). Ricky W. Griffin had a different view of innovation than P. Kotler. He referred them to the activity and effort of an organization to develop new 
products or services, or new applications of existing products or services (Griffin, 2005). One of the most complete definitions of innovation seems to be the one quoted by many scientists, following the Oslo Manual (Oslo Manual, 2008). According to him, "innovation is the implementation of a new or significantly improved product (product or service) or process (Dereli, 2015), a new marketing method or a new organizational method in economic practice, workplace organization or relations with the environment" (Janiszewski and Siemieniuk, 2012). It should be remembered that in light of this definition, an innovation is a new idea or invention that will find practical application in the economy.

There are many divisions of innovation. The classic division of enterprise innovation is the one in which product innovations (introducing a new product, item or service) and process innovations (introducing a new method of operation) are distinguished (Lewin et al., 2009). In addition, the literature on the subject distinguishes social innovations, including the introduction of new customs or social behaviors (Jamielniak and Koźmiński, 2011).There are also (Penc, 2003):

- organizational innovations related to the organization of work and production,

- the so-called eco-innovations that reduce or completely eliminate the negative impact of the production process on the natural environment,

- marketing innovations that are related to marketing strategies,

- technological innovations, which are aimed at introducing new production methods to improve the production process,

- managerial innovations that are related to changes in the processes of managing the enterprise.

The implementation of innovations in an enterprise is always accompanied by change. This, in turn, generates different behaviors of the organization as a whole and of employees as individual members (Yidong and Xinxin, 2013). Resistance and flexibility are two different attitudes of the organization as a whole to the changes brought about by innovation (Yoo et al., 2012). Organizational culture has a significant impact on the success or lack of it in the effective implementation of innovations in the enterprise(Wojtczuk-Turek and Turek, 2015).

Innovation for a company can be both an opportunity and a threat. The implementation of innovations in the enterprise always carries a potential risk (Fáykiss et al., 2018). There are many barriers that may constitute the failure of implementing a given innovation in an enterprise. The literature cites, in particular (Schoemaker et al., 2018):

- functioning under the pressure of current problems and matters to do,

- lack of management continuity and the related tendency of managers to start all over again,

- lack of respect for the achievements of their predecessors,

- low level of social capital,

- low level of mutual trust among individuals, etc.

The condition of Polish enterprises in relation to the level of innovation has been presented in the latest report by the State Agency for Enterprise Development (PARP, 2020). The results of the report entitled "Monitoring the innovativeness of Polish enterprises - the results of the third edition of the survey - 2020" indicate several facts about the innovativeness of Polish enterprises before the pandemic period.

They are as follows (PARP, 2020): 
- $34.7 \%$ of companies operating in Poland were innovatively active in 20172019, which means that they introduced or tried to apply at least one innovation in the company's operations,

- $30.1 \%$ of companies can be described as innovative, i.e. those that have introduced at least one innovation,

- the share of innovative companies, broken down by company size, is: $29.2 \%$ among micro-enterprises, $38.7 \%$ - small enterprises, $43.3 \%$ - medium and $56.7 \%$ - large enterprises,

- the influence of external factors on the innovativeness of companies increased,

- Polish enterprises introduce business process innovations more often (24.5\%) than product innovations (13.1\%),

- new innovations were introduced more often on the company scale $-25.7 \%$ than on the market scale $-6.1 \%$,

- innovative activity of Polish companies is primarily investment outlays in fixed assets, purchase of machinery and equipment (including computer hardware), means of transport and other,

- the main source of innovation in Polish enterprises is the management staff (70\% of innovation active companies), secondly - the external environment of the company: customers, suppliers and competitors (54\%),

- $70 \%$ of all innovatively active companies cooperated with clients in the field of innovative activities, almost half (46\%) with suppliers, and one fifth (22\%) with competitors and other enterprises,

- among the benefits of conducting innovative activities, entrepreneurs indicate: improving the quality of customer service (54\%), increasing the ability to adapt to customer requirements $(51 \%)$, improving the quality of products and services (51\%), increasing work efficiency (43\%), and also acquiring new customers (43\%), strengthening the brand (43\%), increasing sales $(37 \%)$ and increasing net profit (33\%),

- barriers to the development of innovation are market-based: strong competition in the industry (55\% of innovation-active companies) and shortage of qualified employees (41\%) and administrative: bureaucracy (45\%) and inflexible legal regulations (42\%),

- in the opinion of innovatively inactive companies, the most important barrier to starting and running an innovative activity is the belief that it is not justified because it is not necessary in a given industry to achieve market advantage (41\%).

The countries such as Denmark, Sweden, the Netherlands, Finland, Norway and Iceland are considered leaders in implementing various types of innovations in enterprises. For the so-called In turn, the following countries are recognized as "average" in implementing innovations in enterprises: Belgium, Great Britain, Estonia, Luxembourg, Ireland, Germany, Lithuania, Spain, Austria, France, Malta and Portugal. The "outliers" in terms of implemented innovations include: Czechs, Latvians, Slovenes, Hungarians, Slovaks, Poles, Croats, Italians, Greeks, Bulgarians and Romanians (Kisielnicki, 2016).

One of the areas in which many changes related to the implementation of innovations have occurred are finance and accounting. The dynamics of the development of IT 
systems, especially in the field of financial and accounting services for enterprises, forced the implementation of innovations, the task of which was primarily to improve the work of the organization in this area (Gomber et al., 2017). This article is an attempt to penetrate the issues related to the management of innovations in the area of finance and accounting in Polish enterprises of the SME sector.

\section{METHODOLOGY OF RESEARCH}

The research was conducted with the use of a questionnaire on innovation management in the financial sector of small and medium-sized enterprises. The research group consisted of enterprises providing financial and accounting services and enterprises that use innovations in the discussed area in their activities. The questionnaire was obtained electronically from randomly selected enterprises. The selection criterion was the classification to the SME sector and the use of innovations in the area of finance and accounting. The process of obtaining the questionnaires lasted 3 months. 63 responses (questionnaires) were obtained, of which 40 correctly and correctly completed questionnaires were selected for analysis. The proprietary questionnaire consisted of 3 parts. The first part concerned the characteristics of the investigated company, the second part was a package of information characterizing the respondent, while the third part contained 10 problem questions related to the topic. For the most part, the respondents were to evaluate the presented concepts and phenomena on a scale from 1 to 5 . The higher the declared value for a given problem, the more the respondent agreed with it. The results presented in this article are part of a larger whole.

\section{RESULTS}

Based on the results obtained, the following information about the study was obtained.Well, out of 40 economic entities analyzed, 18 belonged to small enterprises (9-49 employees), 17 belonged to medium-sized enterprises, and to the smallest economic entities - 5. The type of activity of the analyzed enterprises is presented in Figure 1. The services were provided by 19 analyzed enterprises, 16 enterprises declared production activity, while 5 enterprises declared trade activity.

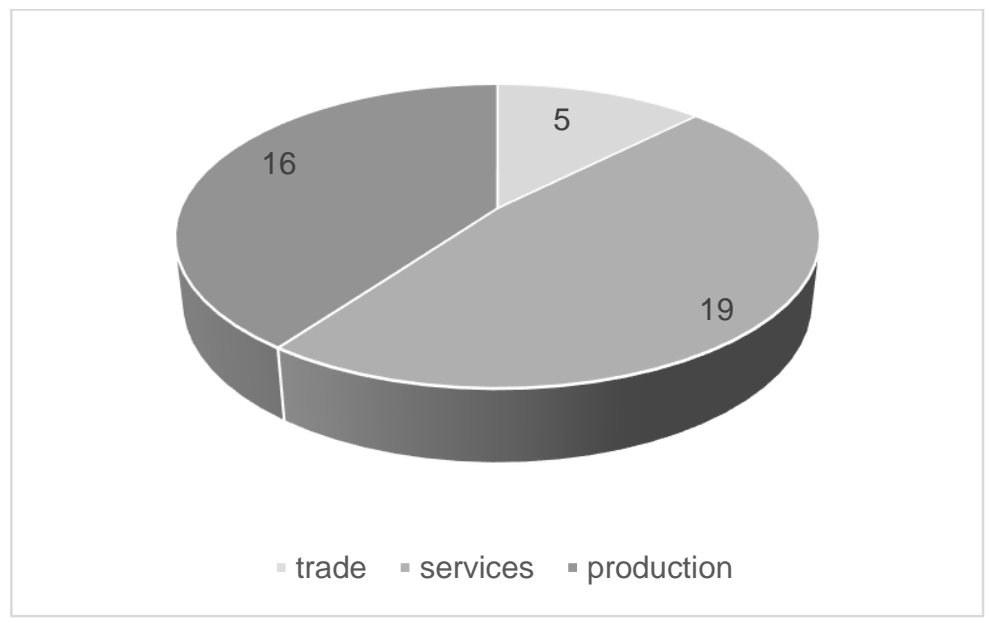

Fig. 1. Type of activity of the analyzed enterprises

The range of activities of individual enterprises is characterized by collective information in Table 1. Local coverage was declared by 3 enterprises, regional 
coverage by 20 , and nationwide coverage was declared by 7 surveyed business entities.

Table 1

Type of activity of the analyzed enterprises

\begin{tabular}{|c|c|c|}
\hline \multicolumn{3}{|c|}{ Business range of enterprises } \\
\hline local & regional & nationwide \\
\hline 3 & 20 & 7 \\
\hline
\end{tabular}

Among all respondents who underwent the survey using the questionnaire, 18 declared being the owner of the surveyed enterprise, while 12 respondents declared work in a managerial position. The remaining respondents - 10 people - declared the employee's position in the survey. 24 women and 16 men answered the questions in the questionnaire. The overwhelming number of respondents constituted a group of employees with work experience between 5-10 years (27 employees). 10 employees declared their work experience in the range of $11-15$ years. Only 3 people, in turn, declared work experience in the range of 16-20 years.

The following data was obtained from the information obtained from the respondents. Well, the majority (38 enterprises) declared that the company they work for is open to new solutions (assigning 4 and 5 points). Only two respondents did not indicate this feature as dominant (they assigned it only 2 points from a 5-point scale).

The same respondents assigned the maximum number of points to the statement that their company works in partnership with customers, trying to develop solutions for them. The respondents indicated the main reason for introducing innovations in companies:

- regulations,

- company development,

- market needs,

- facing competition on the market,

- desire to improve work,

- desire to increase profits.

In the study, the respondents were asked by means of a questionnaire what motivates employees to generate innovative solutions in the company. The highest (4 and 5 points) were the respondents assessed the organization of work, the possibility of promotion, as well as the possibility of personal development and professional development. They assigned lower scores ( 1 and 2 points) to the following factors:

- the opportunity to participate in additional training,

- access to knowledge and information,

- responsibility for finding new ideas.

The respondents also indicated the characteristics of employees that, in their opinion, help to generate innovative solutions. They are presented in table 2. 
Table 2.

Characteristics of employees helping to generate innovative solutions in the surveyed companies in the opinion of the respondents

\begin{tabular}{|c|c|c|c|c|c|}
\hline \multirow[t]{2}{*}{ Feature } & \multicolumn{5}{|c|}{$\begin{array}{l}\text { Number of respondents assessing on a 5-point scale (the higher the } \\
\text { value, the more desirable and important in generating innovative } \\
\text { solutions) }\end{array}$} \\
\hline & 1 & 2 & 3 & 4 & 5 \\
\hline $\begin{array}{l}\text { Learned } \\
\text { knowledge }\end{array}$ & 0 & 5 & 24 & 9 & 2 \\
\hline Experience & 0 & 6 & 20 & 8 & 6 \\
\hline Diligence & 0 & 0 & 10 & 10 & 20 \\
\hline Assertiveness & 0 & 0 & 7 & 12 & 21 \\
\hline $\begin{array}{l}\text { Resilience to } \\
\text { failure }\end{array}$ & 2 & 5 & 10 & 8 & 15 \\
\hline $\begin{array}{l}\text { Commitment } \\
\text { to work }\end{array}$ & 0 & 0 & 5 & 17 & 18 \\
\hline Honesty & 2 & 4 & 19 & 5 & 10 \\
\hline Efficiency & 3 & 4 & 10 & 13 & 10 \\
\hline Creativity & 0 & 0 & 5 & 15 & 20 \\
\hline $\begin{array}{l}\text { Ability to } \\
\text { solve } \\
\text { problems }\end{array}$ & 0 & 0 & 10 & 17 & 13 \\
\hline $\begin{array}{l}\text { Ability to work } \\
\text { under } \\
\text { pressure }\end{array}$ & 0 & 5 & 17 & 10 & 8 \\
\hline $\begin{array}{l}\text { Ability to } \\
\text { cooperate } \\
\text { with other } \\
\text { employees }\end{array}$ & 0 & 0 & 2 & 10 & 28 \\
\hline $\begin{array}{l}\text { Ability to } \\
\text { cooperate } \\
\text { with external } \\
\text { institutions }\end{array}$ & 2 & 5 & 20 & 7 & 6 \\
\hline $\begin{array}{l}\text { Express your } \\
\text { opinion } \\
\text { accurately }\end{array}$ & 6 & 10 & 14 & 5 & 5 \\
\hline $\begin{array}{l}\text { Being up to } \\
\text { date with the } \\
\text { news on the } \\
\text { market }\end{array}$ & 0 & 0 & 15 & 20 & 5 \\
\hline $\begin{array}{l}\text { Fluent } \\
\text { knowledge of } \\
\text { the industry. }\end{array}$ & 0 & 0 & 10 & 17 & 13 \\
\hline
\end{tabular}

The following employee characteristics were given the strongest scores (4 and 5 points) on a 5-point scale (according to the respondents), which help to generate innovative solutions in the company:

- diligence,

- assertiveness,

- commitment to work,

- creativity, 
- ability to solve problems,

- ability to cooperate with other employees,

- being up to date with news on the market,

- fluent knowledge of the industry.

Finally, the respondents were asked to indicate which of the presented innovations in the area of finance and accounting were implemented in their enterprises. Additionally, the respondents could suggest what was the main source of financing a given innovation. Table 3 presents the summary results of this part of the study.

Table 3

Innovations in the financial and accounting area implemented in the surveyed company

\begin{tabular}{|l|c|}
\hline Innovations & Number of respondents \\
\hline e-invoices & 40 \\
\hline Bar codes & 40 \\
\hline RFID tags & 16 \\
\hline Hybrid accounting & 35 \\
\hline Mashup technology & 30 \\
\hline Accounting platforms & 40 \\
\hline
\end{tabular}

The research shows that all enterprises have implemented e-invoices, bar codes and use accounting platforms. Subsequently, the respondents declared the implementation of such innovations in the financial and accounting area as hybrid accounting, Mashup technology. Only 16 of the surveyed companies have implemented RFID labels. The main source of financing for the innovations implemented by enterprises was given by the EU subsidies (20 enterprises), own funds (35 enterprises) and bank loans (10 enterprises). It should be noted that the implementation of individual innovations could be implemented using more than one source of financing.

The respondents also indicated the benefits of the innovations implemented in the financial and accounting area. Out of over 30 benefits indicated in the questionnaire, the highest score (4 and 5 points) was obtained:

- increase of modernity of the company,

- attracting new customers,

- working time reduction,

- reducing the company's operating costs,

- reducing the number of errors compared to previously used traditional methods,

- access to information on a regular basis,

- modernizing the way the company is managed.

The presented results of the conducted research are part of a larger whole, which is the subject of further research and considerations. They will be presented in subsequent scientific papers by the author of this article.

\section{DISCUSSION}

Innovations improving the processes and procedures of enterprises' operations in the area of finance and accounting are not a big novelty these days. Many of them were introduced as a result of legal and organizational changes. According to the conducted research, Polish enterprises are increasingly turning to innovations in the 
area of finance and accounting. Employees of the SME sector more and more often believe that their company is open to new solutions and changes. The reason for introducing innovations is not only the compulsion dictated by legal changes, but also the company's development, market needs, facing competition on the market, the desire to improve work or the desire to increase profit. In turn, the individual motivators for generating innovative solutions in the company are the organization of work, the possibility of promotion, personal development and professional development.Employees see many opportunities in implementing innovation not only for the organization as a structure that needs to be effectively managed, but also for the development of the individual. The features that help them do this include: commitment to work, creativity or the ability to cooperate with other employees. These are features that employees appreciate more than learned knowledge or precise expression of opinions. Social skills and competences, as well as creative thinking and diligence are the features of an employee who is open to changes resulting from the implemented innovations. In the surveyed enterprises of the SME sector, the financial and accounting area was dominated by the implementation of such innovations as accounting platforms, e-invoices, bar codes and hybrid accounting. The sources of financing for these innovations indicated not only the EU subsidies, but also their own funds and bank loans. This proves the growing awareness of the need to implement improvements and innovations in the discussed areas. Despite the fact that Polish enterprises are not in the forefront of countries where the level of innovation is high, in the light of reports, this area of activity of Polish enterprises gives hope for a "better tomorrow". The trends in the activity of Polish enterprises in implementing innovations, including information in the financial and accounting area, show a slight increase compared to previous years. Unfortunately, changes related to the pandemic in the world may change the trend. Therefore, it is very important to continue to monitor the economy and the behavior of enterprises in relation to innovation.

\section{CONCLUSION}

In the era of a dynamically developing economy, innovations are a natural response to market needs. They are about the company's competitiveness and attractiveness. And although Polish enterprises are far from the level of implementing innovations, for example in Swedish or Norwegian enterprises, we understand the need for their implementation and the need to manage them better and better. Unfortunately, the question naturally arises as to how the pandemic will affect the approach of enterprises to innovation. Today, digital transformation has become not only a choice but a necessity. It is also an opportunity for many enterprises that, without this alternative, could be doomed to failure. In the light of reports and reports, there is a growing interest in solutions enabling the provision of remote work, e-commerce or customer service via the Internet. Mobile technologies, cloud solutions, artificial intelligence and business analytics are used more and more often. All this will probably have a positive impact on the next data on innovative activity of enterprises and will probably be continued in the coming years. Automation and digitization of processes requires new competences and investments. It is also still necessary to remember that the possibilities of introducing changes largely depend on the specificity of the industry. While in the industry providing financial and accounting services, changes resulting from implemented innovations largely use IT tools, there 
are industries that provide services such as tourism, hotel, event, cosmetic, hairdressing, etc., which still depend on the physical presence and work of a human being. . For this reason, the subject related to the implementation of innovations in enterprises but also in private (everyday) life seems to be the one that will be subject to further scientific penetrations and discussions.

\section{REFERENCES}

Dereli, D.D., 2015. Innovation Management in Global Competition and Competitive Advantage, Procedia - Social and Behavioral Science, 195 (3), 1365-1370.

Fáykiss, P., Papp, D., Sajtos, P., Törös, A., 2018. Regulatory Tools to Encourage FinTech Innovations: The Innovation Hub and Regulatory Sandbox in International Practice, Financial and Economic Review, 17 (2), 43-67.

Gomber, P., Koch, J.-A., Siering, M., 2017. Digital finance and FinTech: Current research and future research directions, Journal of Business Economics, 87 (5), 537-580.

Griffin, R.W., 2004. Podstawy zarządzania organizacjami, Wyd. Naukowe PWN, Warszawa.

Janiszewski, J.M., Siemieniuk K., 2012. Lean management jako koncepcja wspomagająca zarządzanie innowacjami $w$ przedsiębiorstwie, in: Makroi mikroekonomiczne zagadnienia gospodarowania, finansowania, zarządzania. Studia I Prace Wydziału Nauk Ekonomicznych I Zarządzania, Wyd. Naukowe Uniwersytetu Szczecińskiego, Szczecin, 49-64.

Jemielniak, D., Koźmiński, A.K., 2011. Zarządzanie od podstaw, Wyd. WoltersKluwer, Warszawa.

Kisielnicki J., 2016. Innowacyjność gospodarki polskiej na tle wybranych krajów UE i świata, Studia Ekonomiczne w: Zeszyty Naukowe Uniwersytetu Ekonomicznego w Katowicach, 281, 67-79.

Kotler P., 1994. Marketing - analiza, planowanie, wdrażanie i kontrola, Wyd. Gebethneri S-ka, Kraków.

Lewin, A., Massini, S., Peeters, C., 2009. Why are companies offshoring innovation? The emerging global race for talent, J Int Bus Stud, 40, 901-925.

Oslo Manual, 2008. Zasady gromadzenia i interpretacji danych dotyczących innowacji, OECD.

PARP, 2020. Raport o stanie sektora małych i średnich przedsiębiorstw w Polsce, Wyd. PARP, Warszawa.

Penc, J., 2003. Zarzadzanie w zmieniającym się otoczeniu, Współczesne Zarządzanie, 1, 7-24.

Schoemaker, P.J.H., Heaton, S., Teece, D., 2018. Innovation, Dynamic Capabilities, and Leadership, Californie Management Review, 61 (1), 1-33.

Schumpeter, J., 1960. Teoria rozwoju gospodarczego, Wyd. PWN, Warszawa.

Wojtczuk-Turek, A., Turek, D., 2015. Innovative behaviour in the workplace: The role of HR flexibility, individual flexibility and psychological capital: the case of Poland, European Journal of Innovation Management, 18 (3), 397-419.

Yidong, T., Xinxin, L., 2013. How Ethical Leadership Influence Employees' Innovative Work Behavior: A Perspective of Intrinsic Motivation, J Bus Ethics 116, 441-455.

Yoo Y., Boland R., Lyytinen K., Majchrzak A., 2012. Organizing for Innovation in the Digitized World, Organization Science, 23 (5), 1398-1408. 